\title{
TRAINING OF GERIATRIC SPECIALISTS FOR BUILDING OF COMMUNICATION SKILLS FOR WORK WITH ELDERLY PEOPLE WITH DISABILITIES
}

\author{
Mariya Dimova1, Hristina Milcheva², Albena Andova ${ }^{3}$
}

\begin{abstract}
INTRODUCTION: The development and improvement of medical and social services for people with disabilities is one of the indicators for providing life quality to elderly people. Training of geriatric specialists is one of the ways to overcome the deficiency of professionals possessing specific knowledge and skills to take care of elderly and aged people, with or without disabilities. During their training, the students, majoring in Geriatric Care acquire professional competencies for work with elderly and aged people with or without disabilities (visual disabilities, hearing disabilities, etc). Formation of communication competence in students is an important part of the professiogram. The curriculum envisages diverse training methods, facilitating the formation of skills required for communication with patients, in conformity with their individual characteristics and system of values.
\end{abstract}

AIM: The purpose of this survey is to present the training of geriatric specialists from the Medical College at Trakia University, Stara Zagora, with regards to the formation of communication skills necessary to work with elderly people with disabilities.

MATERIALS AND METHODOLOGY: Examination and analysis of training documentation is done.

RESULTS: The analysis of the training documentation shows that the training of the geriatric specialists at the Medical College of Trakia University, Stara Zagora is entirely conformed to the special, individual characteristics of elderly people with disabilities. The syllabus includes the elements, necessary to build professional competencies for communication with the mentioned target group within the frame of the approved curriculum.

UDC Classification: 614.1, DOI: http://dx.doi.org/10.12955/cbup.v4.848

Keywords: training, geriatric specialists, communication, people disabilities.

\section{Introduction}

According to the European Economic and Social Committee (EESC) "the people with disabilities represent about $16 \%$ of the EU population, i.e. 80 million people. They also represent one sixth of the working people in the EU and $75 \%$ of them are people who probably need intensive support". (European Disability Strategy, 2010-2020)

According to the specificities of the type of disability of this group, the people involved need a specific way of communication with them. (Sharby, Martire \& Maura, 2015).

The people with disabilities need both physical and psychological support.

There is "a close relationship between spiritual and physical interactions for handicapped individuals. This fact emphasizes the influence of physical state and psychological well-being on the emotional driver in a disabled person and their willingness to socialize. The socio-educational support program development for people with disabilities is an effective way to deepen their understanding and enhance the mental awareness of their physical being in order to promote mental well-being, such as confidence, self-esteem, and, ultimately, acceptance" (Sadovski, 2014; Sharby, Martire \& Maura, 2015).

The specialists working with people having visual and hearing disabilities should possess knowledge and skills necessary to provide adequate services to the clients in this target group, in compliance with the requirements of the modern European society which presupposes to guarantee all citizens their

\footnotetext{
${ }^{1}$ Mariya Dimova, Medical College of Trakia University, 9 Armeiska Str, Stara Zagora 6000, Bulgaria, mdimovameister@gmail.com , Phone: +359 895773448

${ }^{2}$ Hristina Milcheva, Medical College of Trakia University, 9 Armeiska Str, Stara Zagora 6000, Bulgaria, hr_mil4eva@abv.bg, Phone: +359899946296

${ }^{3}$ Albena Andonova, Medical Faculty of Trakia University, 11 Armeiska Str, Stara Zagora 6000, Bulgaria, andonova_a@dir.bg Phone: +359898746667
} 
fundamental rights, avoid any discrimination on the basis of their disability and stimulate the process of their integration and reintegration (AltPflG, 2000).

Therefore, the need to train qualified staff in order to afford appropriate services to these people is of major significance.

\section{Purpose}

The purpose of this paper is to present the training of geriatric specialists at the Medical College of Trakia University, Stara Zagora with regards to their training to build communication skills so as to work with elderly people with visual and hearing disabilities.

\section{Methodology}

This is purpose has been achieved by examining and analysing training documentation.

During their training, the students acquired professional competencies for work with elderly and aged people. (Trakia University, Qualification Characteristics of the specialty "Geriatric care", 2015; Trakia University, Curriculum of the specialty "Geriatric care", 2015; Trakia University, Syllabuses of the specialty "Geriatric care", 2015).

Communicating and caring for them in domestic or institutional environment is consistent with their individual characteristics, their values and their personality. (Powell, 2006).

In their training, the students learnt to regard the care as a communication and that it should be done using an approach that is orientated towards the person in need. (European Disability Strategy 20102020; Trakia University, Qualification Characteristics of the specialty "Geriatric care", 2015; Kostov, Milcheva, \& Dimova, 2015; Karl \& Arnold, 2007; Trakia University, Curriculum of the specialty "Geriatric care", 2015; Trakia University, Syllabuses of the specialty "Geriatric care" , 2015; AltPflG, 2000; Powell, 2006).

The Geriatric Care curriculum has been modelled on the German training program for geriatric specialists with certain fields of competence. It is consistent with the specific conditions in Bulgaria and the characteristics of the target group (Trakia University, Curriculum of the specialty "Geriatric care", 2015; AltPflG, 2000).

The developed syllabuses comply with the social and cultural specificities of the target group, keeping in mind circumstances that emerge during the work process (Trakia University, Qualification Characteristics of the specialty "Geriatric care", 2015; Trakia University, Syllabuses of the specialty "Geriatric care", 2015; AltPflG, 2000).

The preset goals include the formation of the following competencies in communication skills to work with people with disabilities:

- having knowledge of the type of disability,

- effective verbal and non-verbal communication with the target group,

- taking into account personal, cultural, ethnical and religious characteristics along with their biographical individuality when caring for elderly people with disabilities,

- having knowledge of possible problems and barriers as well as methods to handle them,

- creating a living space as per criteria, including factors like accessibility,

- organizing their daily routine, in particular, their free time,

- assisting the integration and reintegration of people with disabilities into society,

- having knowledge of legislation frames concerning the target groups,

- having knowledge of disability aids and special technologies, and

- verbal and non-verbal communication skills.

The academic subjects, within the terms of which these communication competencies are built, are:

- theoretical aspects of health care and introduction to the profession,

- institutional and legislative regulations involving care for people in geriatric age, and

- social aspects of care for people in geriatric age 
Figure 1: The developed syllabuses comply with the social and cultural specificities of the target groups and the circumstances, emerging during the work process

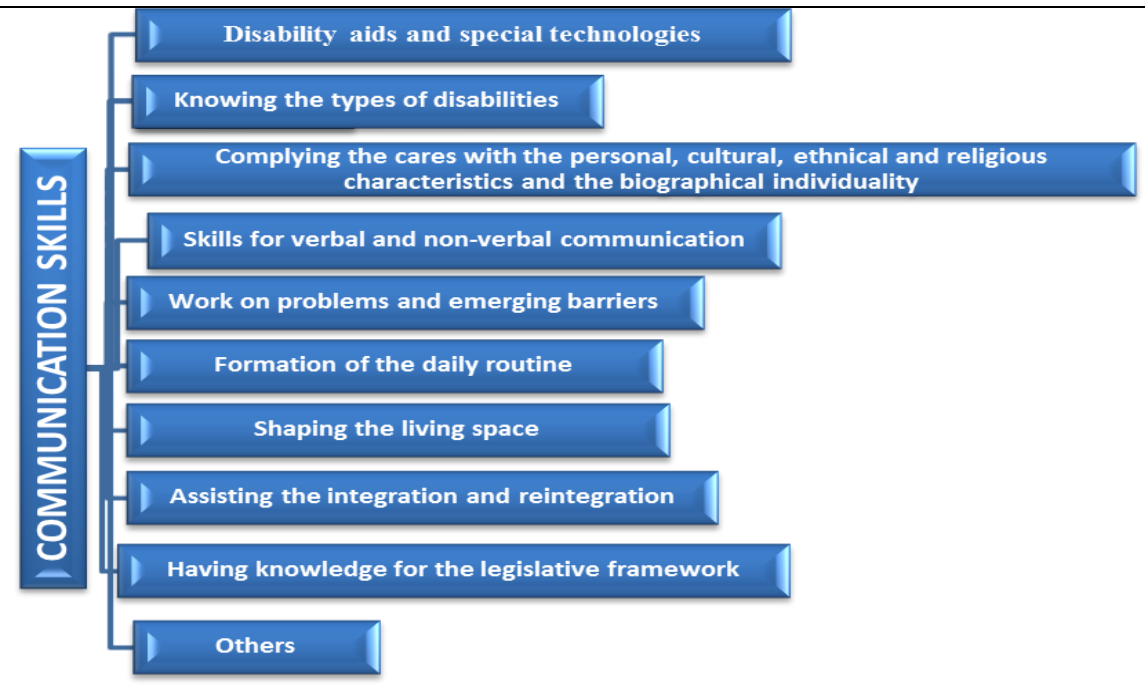

Source: Trakia University, Syllabuses of the specialty "Geriatric care" of the Medical College at Trakia University, Stara Zagora (2015)

\section{Modules}

Based on Trakia University, Curriculum of the specialty "Geriatric care" (2015) and Trakia University, Syllabuses of the specialty "Geriatric care" (2015), following modules are deduced:

- complying with the personal, cultural, ethnical and religious characteristics,

- designing the daily routine,

- planning, documentation and evaluation of the care,

- social aspects of the work with dementia cases,

- communicating and socializing with the elderly,

- sexuality of the elderly and aged people,

- disability aids and technologies involved in rehabilitation of elderly people with disabilities,

- social practice.

All these competencies are described in the Qualification Characteristics of the specialty "Geriatric Care" (Trakia University, Qualification Characteristics of the specialty "Geriatric care", 2015).

During the training, the following methods are used (Trakia University, Syllabuses of the specialty "Geriatric care", 2015):

- Lecture exposition,

- Discourse,

- Discussion,

- Exercises,

- Work with a text,

- Case solving,

- Role games,

- Work in small groups,

- Presentation,

- Video films,

- Seminars,

- Independent out-auditorium work of the students - self-preparation, course work, presentation of cases, etc.,

- Assessment. 


\section{Conclusion}

The analysis of the training documentation shows that the training of geriatric specialists at the Medical College of Trakia University, Stara Zagora is completely consistent with the characteristics of the elderly people with disabilities. The content of the syllabuses and the training methods facilitate the formation of professional competencies for efficient communication with the specified target group within the frames of the approved curriculum.

\section{References}

AltPflG (2000). Gesetz über die Berufe in der Altenpflege (Altenpflegegesetz - AltPflG) [Act on Professions in the elderly (Elderly Care Act - AltPflG )]. Retrieved from https://www.gesetze-im-internet.de/bundesrecht/altpflg/gesamt.pdf

European Disability Strategy (2010-2020). Opinion of theSection for Employment, Social Affairs and Citizenship on the Communication from the Commission to the European Parliament, the Council, the European Economic and Social Committee and the Committee of the Regions - European Disability Strategy 2010-2020: A Renewed Commitment to a Barrier-Free Europe, Brussel (2011). Retrieved from http://eur-lex.europa.eu/LexUriServ/LexUriServ.do?uri=COM:2010: 0636:FIN:en:PDF

Karl, Fr., \& Arnold, R. ( 2007). Rabota s dementno bolni. Opit ot Germany I Bulgaria. Praktichesko pomagalo za nacionalnata konferenci finansirana ot fondacia Robert Bosh, proekt Rabota s dementno bolni [Work with Dementia Cases. Experience from Germany and Bulgaria. A Practical Handbook for the National Conference on the Project, Funded by the Robert Bosch Foundation: "Work with Dementia Cases", 14.09.2007, Kazanlak, Kassel Gerontological Works, vol. 42, Kassel/Kazanlak, (2007)]. Kassel / Kazanlak. Kasseler Gerontologische Schriften Band 42.

Kostov, K., Milcheva, Hr., \& Dimova, M. (2015). Domashni griji. Rakovodstvo za obuchenie na geriatrichni specialist [Home Care. Manual training geriatric specialists]. Stara Zagora. Bulgaria. Akademichno izdatelstvo Trakia university, ISBN 978-954-338-116-6.

Powell, J. (2006), Da pomognem na starite khora s dementsiya, Kasseler Gerontologische Schriften, Kassel. Germany. Bulgarische Übersetzung aus dem englischen Original [Since pomognem na Starite khora s dementsiya, Kassel Gerontological writings, Kassel . Germany . Bulgarian translation of the English Original]: Care to Communicate. Helping the Older Person with Dementia. A Practical Guide for Careworkers. Hawker Publications Ltd. London (2000) Deutsche Fassung: Hilfen zur Kommunikation bei Demenz. Kuratorium Deutsche Altershilfe (KDA) Köln.

Sadovski, M. (2014). SOCIAL ADAPTATION OF PEOPLE WITH DISABILITIES, CBU INTERNATIONAL CONFERENCE ON INNOVATION, TECHNOLOGY TRANSFER AND EDUCATION, PRAGUE, CZECH REPUBLIC, FEBRUARY 3-5. Retrieved from http://ojs.journals.cz/index.php/CBUConference2013/article/view/486/477

Sharby, N., Martire, K., \& Maura, D. (2015). Iversen Decreasing Health Disparities for People with Disabilities through Improved Communication Strategies and Awareness, International Journal of Environmental Research and Public., 12, 33013316, ISSN 1660-4601.

Trakia University (2015). Kvalifikacionna charakteristika na specialnost "Geriatrichni griji, Medicinski kolej, Stara Zagora". [Qualification Characteristics of the specialty "Geriatric care" of the Medical College at Trakia University, Stara Zagora"]. Bulgaria

Trakia University (2015). Ucheben plan na specialnost “Geriatrichni griji”. Medicinski kolej, Stara Zagora [Curriculum of the specialty "Geriatric care" of the Medical College at Trakia University, Stara Zagora].Bulgaria.

Trakia University (2015). Uchebni programi na specialnost "Geriatrichni griji”. Medicinski kolej, Stara Zagora [Syllabuses of the specialty "Geriatric care" of the Medical College at Trakia University, Stara Zagora]. Bulgaria 